\title{
The Library Services Branch and Its Services to Libraries
}

\begin{abstract}
USOE's Library Services Branch administers the Library Services and Construction Act, although not the Higher Education Facilities Act, and sponsors investigation, collects statistics, and renders advisory services of use to libraries. Recent examples of each of these activities are cited, and the provisions of the Higher Education Facilities Act as it pertains to libraries are explained in detail.
\end{abstract}

$\mathrm{T}_{\mathrm{H}}$ Office Library Services Branch of the Office of Education is responsible for (1) administering the Library Services and Construction Act, which applies to public libraries, and (2) study, research, statistical, and advisory services on all types of libraries.

The staff of the Library Services Branch represents all fields of librarianship. There are specialists for public libraries, school libraries, special libraries, college and university libraries, and library education.

Among the several Branch services is the identification of major problems and trends in American librarianship. Examples would include (1) the administration and organization of libraries; (2) the resources, services, and expenditures of libraries; (3) the education, certification, and economic status of library personnel; and (4) the social and economic issues which directly affect libraries-such as the antipoverty program.

The Library Services Branch also studies and disseminates information re-

Mr. Samore is College and University Library Specialist, Library Services Branch, U.S. Office of Education. garding the physical plant and equipment of all types of libraries, and bibliographies in special fields. One of the most recent instances is Nathan Cohen's Library Science Dissertations, 1925-60.

The library education specialist is responsible for collecting and making available nationwide information on professional and semiprofessional programs of education for librarianship. The latest report in this field is the Library Education Directory, 1962-63, which lists library science programs offered throughout the country.

One of the principal responsibilities of the college and university library specialist is the collection, analysis, and preparation for publication and distribution of basic statistical data on academic libraries. The most recent survey, covering 1962/63, was published in January $1964 .^{1}$

This survey gives basic data on collections, personnel, and expenditures of each of 1,463 college and university libraries, grouped by state. It includes li-

\footnotetext{
${ }^{1}$ Library Statistics of Colleges and Universities, 1962-63, Institutional Data (U.S. Department of Health, Education and Welfare, Office of Education, OE15023-63).
} 
brary expenditure per student and the ratio of library expenditures to total institutional expenditures for educational and general purposes, as well as providing high and low salaries of specified full-time staff in almost one thousand institutions as of September 1.

Copies of this report are available without charge. It is sent automatically from the Office of Education to the head librarians of all academic institutions.

A supplement to the January report was compiled by the college and university library specialist and published by the American Library Association; a copy sells for $75 \notin .^{2}$ This publication contains management data of 419 libraries, or 20 per cent of the total number of academic libraries, i.e. those which returned their completed questionnaires after the deadline of September 30. With the original publication and this supplement, administrators and librarians now have management data for 90 per cent of all college and university libraries. Approximately 70 per cent of libraries reporting gave permission to release information on salary data.

The analytical report of the same data, which will be published in early 1965 , will group the information by (1) type of institution and control and by (2) size of enrollment and control. Each category of data is analyzed to show the lowest, 10th percentile, median, mean, 90 th percentile, and highest figures. Special emphasis is placed on relating the analytical findings in three critical areas -collections, professional staff, and institutional support-since these can be measured against appropriate ALA standards for academic libraries.

In August 1964, the Branch once more sent out questionnaires. As was the case last year, most state library agencies co-

\footnotetext{
${ }^{2}$ Supplement to Library Statistics of Colleges and Universities, 1962-63. Institutional Data of $419 \mathrm{Li}$ braries, comp. by the Library Services Branch, U.S. Office of Education (Chicago: Library Administration Div., ALA, 1964).
}

operated in distributing and collecting the questionnaires. This cooperation is the key part of a national data flow scheme which aims to avoid duplication in the collection of data, share the data that are collected, fill any gaps in the compilation of data, collect comparable and uniform data, and-last-expedite the entire process. The results of such cooperation have been a greater quantity and better quality of returns.

Many library associations are also assisting with these statistical studies. The Association of College and Research Libraries, the Association of Research Libraries, the College and University Library Statistics Committee of LAD-ALA, the Catholic Library Association, the American Theological Library Association, and the American Association of Junior Colleges assisted in various phases of last year's survey. They have also participated in the planning for this year.

All of these data are designed for the use of all institutions furnishing information.

This statistical information is useful in a variety of ways:

1. It furnishes factual bases for comparing library resources and services with ALA Standards.

2. It furnishes information which assists in budget planning and self-studies.

3. It provides guidelines to accrediting associations and academic library consultants.

4. It yields an accurate picture of academic library progress and development.

5. It provides a reliable source of salary information for various levels of library positions.

The Branch offers consultant service on college and university libraries which is available on request as time and travel funds permit.

Every effort is made to identify authoritative sources of information to meet the requests of inquirers, and, 
whenever possible, to provide them with answers or to refer them directly to these sources and agencies. Statistical information can be supplied directly by the Branch either in IBM punched-card form or as a printout. There is no charge for this service.

Here are a few examples: Warren Haas of Columbia University will compare the resources and services of Negro college libraries with all other college libraries on the basis of data furnished by the Branch. The Reverend Charles Banet published in Catholic Library World a detailed article on library statistics of Catholic colleges and universities, and James T. McDonough of St. Joseph's College, Philadelphia, is preparing a comparative study on the libraries in liberal arts colleges based on information secured from the Branch.

None of these services would be available without the cooperation of every college and university. Every year each institution provides the data on statistical questionnaires. The Branch, in return, endeavors to make tabulated data quickly and easily accessible to all institutions.

The Branch has had many questions about the Higher Education Facilities Act of 1963, which includes provision for the construction of libraries. The act will be administered by the Bureau of Higher Education Facilities of the United States Office of Education, not by the Library Services Branch.

\section{TrTLE I}

1. This title establishes a five-year program of grants to institutions of higher education for the construction of academic facilities. The appropriation authorization for each of the first three fiscal years, commencing with the fiscal year ending June 30,1964 , is specified in the statute as two hundred thirty million dollars.

2. The appropriation for any fiscal year is divided into two parts for allotment among the states (including the District of Columbia, the Commonwealth of Puerto Rico, the Virgin Islands, Guam, and American Samoa):

a. Twenty-two per cent of the appropriation is allotted on the basis of a state's relative per capita income and number of high school graduates. A state's allotment from this fund can be used only for public community colleges and public technical institutes.

b. The remaining 78 per cent of the appropriation is allotted as follows: one half on the basis of the relative number of students enrolled in grades 9 through 12 in the state and one half on the basis of the relative number of students enrolled in institutions of higher education in such state. The allotment from this fund is available for grants to institutions of higher education, public and private, in the state (other than public community colleges and public technical institutes).

3. Institutions of higher education other than public community colleges and public technical institutes are eligible for construction grants only if the construction is limited to structures (or portions thereof) especially designed for instruction or research in the natural or physical sciences, mathematics, or modern foreign languages, engineering, or for use as a library; and all institutions of higher education (including public community colleges and public technical institutes) are eligible for a grant for construction only if the particular construction will, either alone or together with other construction to be undertaken within reasonable time, result in an urgently needed substantial expansion of the institution's student enrollment capacity, or in the case of a new institution of higher education, result in creating urgently needed enrollment capacity. 4. A state desiring to participate in 
the grant program under this title must designate, as the "state commission," an existing state agency which is broadly representative of the public and of institutions of higher education (including junior colleges and technical institutes) in that state, or if no such state agency exists, establish such a state agency, and submit to the Office of Education through such commission a state plan for participation under title I.

5. Among the provisions required in a state plan is the setting forth of objective standards and methods, consistent with basic criteria prescribed by the Commissioner of Education, for determining (a) relative priorities of eligible projects for the construction of academic facilities submitted by institutions of higher education in the state and $(b)$ the federal share of the cost of each such project (other than a project for a public community college or public technical institute).

6. While the federal share of a project for an institution of higher education, other than a public community college or a public technical institute, may vary up to a maximum of one-third of the cost, the federal share of a project for 2 public community college or a public technical institute is fixed by the law at 40 per cent.

\section{TITLE II}

1. This title establishes a five-year program of construction grants (covering up to $33 \frac{1}{3}$ per cent of the costs) to assist public and private institutions of higher education to improve existing graduate schools and cooperative graduate centers and to assist in the establishment of graduate schools and cooperative graduate centers of excellence. Appropriation authorizations for the first three years are specified in the statute; i.e., twenty-five million dollars for fiscal year 1964 and sixty million dollars for each of the next two succeeding fiscal years.
2. In approving applications the Commissioner is required to consider the extent to which a particular project will contribute to achieving the objective of this title-which is to increase the supply of highly qualified personnel urgently needed by the community, industry, government research, and teaching-and also the extent to which the grant will aid in attaining a wider geographical distribution of graduate schools and cooperative graduate centers.

3. This title also establishes in the Office of Education an advisory committee on graduate education to advise the Commissioner on the administration of the program, including the action to be taken on applications for grants under this title.

\section{TITLE III}

1. This title authorizes a five-year program of loans for the construction of academic facilities at institutions of higher education. The appropriation authorized for each of the first three fiscal years commencing with the fiscal year ending June 30,1964 , is specified in the act as one hundred twenty million dollars.

2. The loans will bear an interest rate, determined by the Commissioner, which cannot be less than one-quarter of 1 per cent above the average annual interest rate on all federal obligations. The maximum period for repayment of a loan is fifty years.

3. An institution applying for a loan will have to show that not less than onefourth of the development cost of the project will be financed from non-federal sources and that it cannot borrow from other sources on equally favorable terms.

\section{ExCLUSIONS}

The following are not considered academic facilities for which grants or loans for construction may be made under the act: 
1. Any facility intended primarily for events for which admission is charged to the public.

2. Any gymnasium or other facility specially designed for athletic or recreational activities, other than a course in physical education.

3. Any facility used or to be used for sectarian instruction or religious worship.

4. Any facility used or to be used primarily for any part of the program of a school or department of divinity.

5 . Any facility used or to be used by a school of medicine, dentistry, osteopathy, pharmacy, optometry, podiatry, nursing, or public health.

Appropriations to implement the Act for fiscal year 1965 have been requested by the Administration. In April 1964 the House approved the following amounts:
Title I

Title II

Title III .

This is just a beginning. In his speech before the First General Session of the American Library Association conference in St. Louis, Mr. Keppel remarked that: "The Higher Education Facilities Act, with its help to academic library construction, comes none too soon ... . but the unfinished job-the hardest jobstill remains. It is to build adequate collections of books and other materials needed by college students and faculty for their study and research. This is both an immediate and a long term, continuing task. A library without books, of course, is about as useful to learning as an empty warehouse."

\section{AUTOMATED OPERATIONS IN A UNIVERSITY LIBRARY}

(Continued from page 29)

and dealers' prices and discounts, and it can compare the time required by various dealers to fill orders. It can compare the items on an invoice with the acquisitions and serials units' receipt records stored in the computer catalog to determine whether or not the items on the invoice have been received. Supply inventory control with automatic ordering is an obvious routine for such a system, as is equipment inventory control.

\section{LibraRy Office Routines}

Among the uses for computers in library office routines that readily come to mind is a KWIC index of library correspondence, minutes of meetings, library reports, memoranda, and other papers that might inform the left hand about the doings of the other hands.

Needless to point out would be the value of lists of personnel and their assignments, telephone numbers, etc., updated whenever changes occur.
There is also no reason why the library's important correspondence, minutes, reports, etc., could not be stored in microform and tied into the technical reports retrieval system previously described, with or without the KWIC index.

If the library is responsible for its own personnel records, there could be many possibilities for further useful data collection and evaluation. Beyond the usual personnel data maintained by any organization, information can be listed as to special training or talents, foreign languages studied, travel experiences, hobbies or any other data that may be useful to reference librarians looking for answers to questions.

There are, of course, other ways in which automation can be of service to librarians and their patrons. Each librarian, as he becomes familiar with the advantages and limitations of computers and as he learns the theories and techniques of data processing, will find his own uses for this new medium. 